\title{
Article/Artigo
}

\section{Prevalence of intestinal parasites in preschool children in the region of Uberlândia, State of Minas Gerais, Brazil}

\author{
Prevalência de parasitoses intestinais em crianças institucionalizadas na região de Uberlândia, \\ Estado de Minas Gerais
}

\author{
Ana Lúcia Ribeiro Gonçalves ${ }^{1,2}$, Talita Lucas Belizário ${ }^{2,3}$, Janderson de Brito Pimentel ${ }^{2}$, Mário Paulo Amante \\ Penatti ${ }^{2}$ and Reginaldo dos Santos Pedroso ${ }^{2}$
}

\begin{abstract}
Introduction: Children are an important high-risk group for helminth and protozoa infections. Daycare centers are environments where children have proven to be more susceptible to acquiring intestinal parasites. Thus, the purpose of this study was to verify the prevalence of intestinal parasites in children who attended the two daycare centers maintained by the local government of Uberlândia, State of Minas Gerais, Brazil. Methods: Fecal samples were collected from 133 children ( 73 children at the Public Preschool for Early Childhood Education, PPECE $\mathrm{A}$, and 60 at the PPECE B) following identification according to sex and age and agreement to participate by parents or guardians who signed the free, informed consent form. The samples were examined by the Lutz method. Results: Coproparasitological tests performed on 133 children showed that $29.3 \%$ of them were parasitized for enteroparasites or commensals, $6.7 \%$ of the children presented polyparasitism. Among the protozoa, Giardia lamblia were the most prevalent and Hymenolepis nana were the most frequent among the helminths. Conclusions: Thus, analysis of the results showed that intestinal parasites still represent a public health problem, especially among children and in areas where the socioeconomic and educational conditions are less favorable.
\end{abstract}

Keywords: Intestinal parasites. Daycare centers. Health education.

\section{RESUMO}

Introdução: As crianças são importantes grupos de risco para infecções por helmintos e protozoários. Os centros de educação infantil são ambientes onde as crianças estão mais expostas à infecção por parasitas intestinais. O objetivo deste estudo foi verificar a prevalência de parasitas intestinais em crianças de duas creches mantidas pelo governo municipal de Uberlândia, Minas Gerais, Brasil. Métodos: Os exames coproparasitológicos foram realizados em 133 crianças ( 73 crianças da Escola Municipal de Educação Infantil - EMEI A e 60 da EMEI B), depois da identificação da criança de acordo com a idade e sexo, e concordância dos responsáveis através do Termo de Consentimento Livre e Esclarecido. As amostras foram examinadas pelo método de Lutz. Resultados: Os exames coproparasitológicos demonstraram que $29,3 \%$ delas estavam parasitadas por enteroparasitos ou comensais e 6,7\% das crianças apresentaram poliparasitismo. Entre os protozoários, Giardia lamblia foi o mais prevalente, enquanto Hymenolepis nana foi mais frequente dentre os helmintos. Conclusões: Assim, podemos observar que as parasitoses intestinais ainda representam um problema de saúde pública, especialmente entre as crianças e em áreas onde as condições socioeconômicas e educacionais são menos favoráveis.

Palavras-chaves: Parasitas intestinais. Creches. Educação em saúde.

\footnotetext{
1. Laboratório de Parasitologia, Instituto de Ciências Biomédicas, Universidade Federal de Uberlândia, Uberlândia, MG. 2. Curso Técnico em Análises Clínicas, Escola Técnica de Saúde, Universidade Federal de Uberlândia, Uberlândia, MG. 3. Laboratório de Biologia, Instituto Federal de Educação Tecnológica, Uberlândia, $\mathrm{MG}$.

Address to: Dr. Reginaldo dos Santos Pedroso. Curso Técnico em Análises Clínicas/ESTES/UFU. Av. Amazonas s/n, Bloco 4K/sala 123, Umuarama, 38400-902 Uberlândia, MG, Brasil.

Phone: 5534 3218-2218; Fax: 5534 3218-2410

e-mail: rpedroso@estes.ufu.br

Received in $25 / 10 / 2010$

Accepted in 25/11/2010
}

\section{INTRODUCTION}

The incidence of intestinal parasites is known to be high, generally affecting human health and causing great public health concern ${ }^{1,2}$. This is more common especially in developing or underdeveloped countries, in which actions to control enteroparasites are made more difficult by the financial costs of technical measures (infrastructure) and due to the lack of educational projects that provide the population with information ${ }^{3,4}$.

It has been estimated that infections caused by intestinal protozoa and helminths affect 3.5 billion people worldwide and cause disease in approximately 450 million people, most of whom are children ${ }^{5,6}$.

Children are an important high-risk group for helminth and protozoa infections. Daycare centers are environments where children have proven to be more susceptible to acquiring intestinal parasites, due to the facility of interpersonal contact (childchild, child-functionary), poorly-trained staff and inadequate hygiene conditions inherent in children ${ }^{4,7}$.

In Uberlândia, the rate of intestinal parasitism varies according to age, as reported in several studies $^{8-10}$, reaching up to $60 \%$ of children parasitized in some institutions ${ }^{11}$.

The objective of the present study was to determine the prevalence of intestinal parasites among children attending two public daycare centers in the City of Uberlândia, State of Minas Gerais, Brazil, between August 2008 and November 2009.

\section{METHODS}

\section{Study population}

Uberlândia is a municipality in the Brazilian State of Minas Gerais. It has 634,345 inhabitants and is located in the west of the state in the Triângulo Mineiro region. There are about 57 preschools/ 
daycare centers which cater for children from four months to five years of age and had approximately 13,538 children were enrolled in this age group in 2009.

In this research, children from six months to six years of age, who attended two public daycare centers in this city were studied. Parents or guardians signed the free, informed consent form, agreeing to the participation of the children. They were then identified according to sex and age and 133 fecal samples were collected: 73 from children attending the Public Preschool for Early Childhood Education (PPECE) A and 60 from children attending the PPECE B.

For the cross-sectional study, the sample size was calculated ${ }^{12}$ according to the formula: $\mathrm{n}=\mathrm{Z}^{2} \times \mathrm{P} \mathrm{Q} / \mathrm{d}^{2}$, in which $(\mathrm{Z})$ was $90 \%$, (d) was $10 \%$ and (P) was $58.1 \%$ (obtained from a study on enteroparasites and commensals among children in Uberlândia $\left.{ }^{6}\right)$, and a non-observed value $(\mathrm{Q})$ of $41.9 \%$, and thus the sample size (n) was determined as 66 people and this number was increased to 133 .

\section{Collection of fecal samples}

Three fecal samples from each child were collected in plastic vials containing $10 \%$ formaldehyde as a preservative, at intervals of two to four days. The samples were collected by parents or relatives or by the educator at the daycare centers, stored in boxes and analyzed at the Laboratory of Technical School Health of the Uberlandia Federal University (Universidade Federal de Uberlândia, UFU) using the Lutz method $^{13}$. Three slides of each sample were prepared and examined by two analysts, such that six slides per sample were analyzed.

\section{Community return}

All the families of the children received the results of the laboratory diagnosis. The positive cases were referred to appropriate healthcare units, where they received specific treatment.

\section{Data analysis}

Statistical analysis was performed using the rate of positive findings expressed as a percentage and the differences between the two groups were analyzed by the $t$ test (Graphpad Prism software version 5.0, Graph Pad Software, Inc.). $P$ values $<0.05$ were considered statistically significant. The confidence interval (CI) was considered as $95 \%$.

\section{Ethical considerations}

All procedures were conducted according to the Research Ethics Committee of the UFU, protocol no. 062/09 and a consent to participate document was sent to the children's parents or legal guardians, to obtain their consent for the child's participation in the study. Furthermore, instructions on how to collect the feces were also provided in writing to the parents or guardians of the children.

\section{RESULTS}

The coproparasitological tests of 133 children ( 73 attending the PPECE A and 60 attending the PPECE B) showed that 39 (29.3\%) of them were parasitized by enteroparasites or commensals, with $30(22.6 \%)$ presenting monoparasitism and 9 (6.7\%) presenting polyparasitism. Polyparasitism occurred with Endolimax nana and Entamoeba hartmanni (1 occurrence), Entamoeba coli and Iodamoeba butschlii (2 occurrences), Giardia lamblia and E. nana (4 occurrences), G. lamblia and Entamoeba histolytica (1 occurrence), Hymenolepis nana and G. lamblia (1 occurrence).
The parasitized children were distributed between the preschools as follows: PPECE A 24 (32.9\%; 95\%CI: 21.5 - 42.7) and PPECE B 15 (25\%; 95\%CI: 24.09 - 25.32). Table 1 shows the occurrence of intestinal parasites and commensals detected in the children according to age and daycare center. According to age, no statistically significant difference was observed between the two daycare centers or within each daycare center.

The distribution of intestinal parasites and commensals diagnosed is shown in Table 2. The results revealed that G. lamblia, E. nana and E. coli showed higher prevalence.

TABLE 1 - Prevalence of intestinal parasites and commensals per age identified in children from two daycare centers in the City of Uberlândia, State of Minas Gerais.

\begin{tabular}{|c|c|c|c|c|}
\hline \multirow[b]{2}{*}{ Daycare center/age (years) } & \multicolumn{2}{|c|}{$\begin{array}{c}\text { Samples } \\
\text { (per daycare center) }\end{array}$} & \multicolumn{2}{|c|}{$\begin{array}{l}\text { Positive cases } \\
\text { according to age }\end{array}$} \\
\hline & $\mathrm{n}$ & $\%$ & $\mathrm{n}$ & $\%$ \\
\hline \multicolumn{5}{|l|}{ PPECE A } \\
\hline$\leq 1$ & 21 & 28.8 & 7 & 33.3 \\
\hline $1 ך 2$ & 9 & 12.3 & 5 & 55.6 \\
\hline 273 & 19 & 26.0 & 5 & 26.3 \\
\hline 374 & 16 & 21.9 & 5 & 31.3 \\
\hline 475 & 8 & 11.0 & 2 & 25.0 \\
\hline \multicolumn{5}{|l|}{ PPECE B } \\
\hline$\leq 1$ & 2 & 3.3 & 1 & 50.0 \\
\hline $1 ך 2$ & 7 & 11.7 & 3 & 42.9 \\
\hline 273 & 6 & 10.0 & 0 & 0.0 \\
\hline 3$\urcorner 4$ & 14 & 23.3 & 4 & 28.6 \\
\hline 475 & 14 & 23.3 & 4 & 28.6 \\
\hline 576 & 17 & 28.4 & 3 & 17.6 \\
\hline
\end{tabular}

PPECE A/PPECE B: Public Preschool for Early Childhood Education A and B.

TABLE 2 - Prevalence of intestinal parasites and mono and polyparasitism identified in children from two daycare centers of the City of Uberlândia, State of Minas Gerais.

\begin{tabular}{lrc}
\hline & \multicolumn{2}{l}{ Positive findings } \\
\cline { 2 - 3 } Intestinal parasites and commensals & $\mathrm{n}$ & $\%$ \\
\hline Giardia lamblia & 26 & 19.2 \\
\hline Endolimax nana & 19 & 14.3 \\
\hline Entamoeba coli & 16 & 12.0 \\
\hline Entamoeba histolytica & 5 & 3.8 \\
\hline Iodamoeba butschlii & 3 & 2.3 \\
\hline Hymenolepis nana & 3 & 2.3 \\
\hline Enterobius vermicularis & 2 & 1.5 \\
\hline Hookworm & 1 & 0.8 \\
\hline Entamoeba hartmanni & 2 & 1.5 \\
\hline
\end{tabular}

\section{DISCUSSION}

In the present study, positivity of $29.3 \%$ was determined for enteroparasites or carriers of a commensal protozoa. This result is considered high and it confirms previous data verified in the City of Uberlândia ${ }^{6,14,15}$.

In previous studies, the authors suggested that the age category most susceptive to parasitic infection is from zero to 15 years of age $e^{6,15}$. The present data showed that of the 133 children examined, $9(6.7 \%)$ involved those aged one to two years-old, 5 (55.6\%) of 
these children were infected with one pathogenic intestinal parasite and contributed to $12.2 \%$ of the positive cases.

Among the enteroparasites and commensals identified, G. lamblia was the most frequent and the only pathogenic protozoa detected. However, this data showed lower occurrence than the results from others studies conducted on this protozoan in the same city ${ }^{15}$. According to Menezes et $\mathrm{al}^{16}$, the prevalence of this parasite is higher in children than in adults, especially in daycare centers, where the lack of hygienic habits and the precarious sanitary conditions facilitate close contact with the infecting forms. These factors, in addition to low immunity against the parasite, result in a high level of infection.

The low occurrence of helminthes in the daycare centers, especially Enterobius vermicularis may be associated with the use of a nonspecific method. The results obtained were lower than literature data obtained using a specific method ${ }^{n}$. Few studies concerning the frequency of parasitoses in children identified E. vermicularis eggs by the Graham method ${ }^{17}$, so the true prevalence of this helminth could be underestimated in many reports ${ }^{4,18,19}$.

The commensal protozoa identified were E. coli, E. histolytica, E. hartmanni, I. butschlii and E. nana. Knowledge regarding the presence of commensal parasites is important because it indicates that the child has entered the transmission cycle of parasites, showing that actions concerning educational activities are necessary in this study group.

According to Franco \& Cordeiro ${ }^{7}$ and Carvalho et $\mathrm{al}^{4}$, daycare centers are one of the environments in which children are susceptible to intestinal parasites and have acquired fundamental importance in the care of preschoolers, since women's participation in the labor market has increased. Moreover, in daycare centers, the accentuated risk of exposure to enteroparasites is due to characteristics inherent to these establishments, including the facility for interpersonal contact (child-child, child-staff member), poorly-trained staff and inadequate hygiene conditions inherent to children, such as the immaturity of the immune system, the oral phase of exploration, hygiene habits still in formation and constant intimate contact with soil.

Observation established that a sanitary education program is necessary to control enteroparasites and commensals with the objective of improving the health of children who attend daycare centers. Thus, it is important to consider the dissemination of information concerning intestinal parasites as an educational activity for self-care, aimed at prophylaxis, for example, good hygiene practices like hand washing and cleaner food preparation.

\section{ACKNOWLEDGMENTS}

The authors are grateful to Sandra Moreira de Souza, Maria Raquel de Melo Peixoto and Lucélia Carlos Ramos for support in contacting the families of the children.

\section{CONFLICT OF INTEREST}

The authors declare that there is no conflict of interest.

\section{FINANCIAL SUPPORT}

This study was supported by grants from the Pró-Reitoria de Extensão, Cultura e Assuntos Estudantis (PROEX-UFU), the Coordenação de Aperfeiçoamento de Pessoal de Ensino Superior (CAPES) and the Fundação de Apoio à Pesquisa do Estado de Minas Gerais (FAPEMIG).

\section{REFERENCES}

1. Stephenson LS. Los helmintos, importante factor de malnutrición. Foro Mund Salud 1994; 15:184-187.

2. Tashima NT, Simões MJS, Leite CQF, Fluminha A, Nogueira MA, Malaspina AC. Classic and Molecular study of Giardia duodenalis in children from a daycare center in the región of Presidente Prudente, São Paulo, Brazil. Rev Inst Med Trop Sao Paulo 2009; 51:19-24.

3. Ludwig KM, Frei F, Alvares FF, Ribeiro-Paes JT. Correlação entre condições de saneamento básico e parasitoses intestinais na população de Assis, Estado de São Paulo. Rev Soc Bras Med Trop 1999; 32:547-555.

4. Carvalho TB, Carvalho LR, Mascarini LM. Occurrence of enteroparasites in day care centers in Botucatu (São Paulo State, Brazil) with emphasis on Cryptosporidium duodenalis and Enterobius vermicularis. Rev Inst Med Trop Sao Paulo 2006; 48:269-273.

5. Schuster H, Chiodini PL. Parasitic infections of intestine. Curr Opin Infect Dis 2001; 14:587-591.

6. Machado RE, Santos DS, Costa-Cruz JM. Enteroparasites and commensal among children in four peripheral districts of Uberlândia, State of Minas Gerais. Rev Soc Bras Med Trop 2008; 41:581-585.

7. Franco RMB, Cordeiro NS. Giardiose e criptosporidiose em creches no município de Campinas, SP. Rev Soc Bras Med Trop 1996; 29:585-591.

8. Ferreira P, Lima MR, Oliveira FB, Pereira MLM, Ramos LBM, Marçal MG et al. Occurrence of intestinal parasites and commensal organisms among schoolchildren living in a 'landless farm workers' settlement in Campo Florido, Minas Gerais, State Brazil. Rev Soc Bras Med Trop 2003; 36:109-111.

9. Ferreira CB, Marçal Jr O. Enteroparasitoses em escolares do distrito de Martinésia, Uberlândia, MG: um estudo piloto. Rev Soc Bras Med Trop 1997; 30:373-377.

10. Rezende CHA, Costa-Cruz JM, Gennari-Cardoso ML. Enteroparasitoses em manipuladores de alimentos de escolas públicas em Uberlândia (Minas Gerais), Brasil. Rev Panam Salud Publica 1997; 2:392-397.

11. Silva JJ, Borges R, Silveira AC, Silva LP, Mendes J. Enterobiasis and other intestinal parasitoses in children attending educacional institutions in Uberlândia, State of Minas Gerais, Brazil. Rev Pat Trop 2003; 32:87-94.

12. Rodrigues PC. Bioestatística. Niterói: Editora Universitária; 1986.

13. Lutz A. Schistosoma mansoni e a schistosomose segundo observações feitas no Brasil. Mem Inst Oswaldo Cruz 1919; 11:121-155.

14. Berbet-Ferreira M, Costa-Cruz JM. Parasitas intestinais em lactentes de 4 a 12 meses, usuários das creches da Universidade Federal de Uberlândia, Minas Gerais. J Pediatr (Rio J) 1990; 71:219-222.

15. Machado ER, Costa-Cruz JM. Strongyloides stercoralis and other enteroparasites in children at Uberlândia City, State of Minas Gerais, Brazil. Mem Inst Oswaldo Cruz 1998; 93:161-164.

16. Menezes AL, Lima VMP, Freitas MTS, Rocha MO, Silva EF, Dolabella SS Prevalence of intestinal parasites in children from public daycare centers in the city of Belo Horizonte, Minas Gerais, Brazil. Rev Inst Med Trop Sao Paulo 2008; 50:57-59.

17. Graham CF. A device for the diagnosis of Enterobius vermicularis. Am J Trop Med Hyg 1941; 21:159-161

18. Dias MT, Grandini AA. Prevalência e aspectos epidemiológicos de enteroparasitoses na população de São José da Bela Vista, SP. Rev Soc Bras Med Trop 1999; 32:63-65.

19. Giraldi N, Vidotto O, Navarro IT, Garcia JL. Enteroparasites prevalence among daycare and elementary school children of municipal schools, Rolândia, PR, Brazil. Rev Soc Bras Med Trop 2001; 34:385-387. 